\title{
The heterodimeric primase from the Euryarchaea Pyrococcus abyssi: a multifunctional enzyme for initiation and repair ?
}

\author{
Magali Le Breton ${ }^{1}$, Ghislaine Henneke ${ }^{1}$, Cédric Norais $^{2}$, Didier Flament ${ }^{1}$, Hannu Myllykallio ${ }^{2}$, \\ Joël Querellou ${ }^{1}$, Jean-Paul Raffin ${ }^{1, *}$
}

\author{
${ }^{1}$ Laboratoire de Microbiologie des Environnements Extrêmes, UMR6197, Ifremer, BP 70, F-29280 Plouzané, \\ France
}

${ }^{2}$ Institut de Génétique et Microbiologie, Université Paris-Sud, UMR8621, 91405 Orsay, France

*: Corresponding author : Raffin J-P., email : jpraffin@ifremer.fr

\begin{abstract}
:
We report on the characterization of the DNA primase complex of the hyperthermophilic archaeon Pyrococcus abyssi (Pab). The Pab DNA primase complex is composed of the proteins Pabp41 and Pabp46, which show sequence similarities to the p49 and p58 subunits, respectively, of the eukaryotic polymerase a-primase complex. Both subunits were expressed, purified, and characterized. The Pabp41 subunit alone had no RNA synthesis activity but could synthesize long (up to $3 \mathrm{~kb}$ ) DNA strands. Addition of the Pabp46 subunit increased the rate of DNA synthesis but decreased the length of the DNA fragments synthesized and conferred RNA synthesis capability. Moreover, in our experimental conditions, Pab DNA primase had comparable affinities for ribonucleotides and deoxyribonucleotides, and its activity was dependent on the presence of $\mathrm{Mg} 2+$ and $\mathrm{Mn} 2+$. Interestingly, Pab DNA primase also displayed DNA polymerase, gap-filling, and strand-displacement activities. Genetic analyses undertaken in Haloferax volcanii suggested that the eukaryotic-type heterodimeric primase is essential for survival in archaeal cells. Our results are in favor of a multifunctional archaeal primase involved in priming and repair.
\end{abstract}

Keywords: DNA replication; Archaea; DNA primase; gap filling; strand displacement 


\section{Introduction}

Archaea constitute the third domain of life ${ }^{1}$ and appear to be a mosaic of bacterial, eukaryotic and unique features. Study of this domain is therefore of high value for understanding the evolution of cellular processes and in particular the mechanisms of DNA replication. In all organisms, DNA replication is a crucial process for cell survival and evolution, involving dozens of proteins and enzymes to ensure the accurate and timely duplication of genetic information. Moreover, many archaea grow in the most extreme environments on Earth. It is, thus, of considerable biological as well as biotechnological interest to determine how the replication machinery has adapted to diverse environmental conditions (for instance extreme temperature, $\mathrm{pH}$ or salt conditions) and how these different conditions have affected the structural, functional and biochemical properties of these proteins. Sequence analyses of archaeal genomes show that most archaeal replication factors are similar to their eukaryotic counterparts. ${ }^{2}$ The archaeal replication machinery appears to be a simplified model of the eukaryotic replisome, with fewer polypeptides and simpler composition of DNA replication complexes. Archaea can thus provide a useful model to elucidate essential conserved aspects of replication.

Most of our knowledge about archaeal DNA replication is linked to factors implicated in the elongation phase (e.g., PCNA, RF-C, RPA and DNA polymerases). Because replicative DNA polymerases cannot initiate DNA synthesis, specialized enzymes, called DNA primases, initiate replication by synthesizing RNA primers on both the leading and lagging strands. Replicative DNA polymerases then use these primers to duplicate the genome. In Bacteria, DNA primase consists of a single subunit, as in the Escherichia coli DnaG, which associates with the replicative DNA helicase. ${ }^{3}$ Interactions between DnaG and the DNA polymerase III replicative holoenzyme limit the size of the nascent primer to $9-14$ nucleotides. ${ }^{4}$ On the other hand, eukaryotic primase is composed of a small catalytic subunit (p49) tightly associated 
with a large subunit (p58) that modulates the stability, the DNA binding and the synthetic capability of the enzyme. ${ }^{5}$ These two subunits are found in complex with two other proteins, the DNA polymerase $\alpha(180 \mathrm{kDa})$ and $\mathrm{B}(70 \mathrm{kDa})$ subunits, to form the pol $\alpha$-primase complex. ${ }^{3}$ The $\mathrm{p} 49 / \mathrm{p} 58$ core of the eukaryotic primase synthesizes a short RNA primer, typically 8-12 nucleotides, and the DNA polymerase $\alpha$ elongates this RNA primer to about 30 nucleotides to generate the RNA-DNA primer. This primer, in turn, can be elongated by replicative DNA polymerases (pols $\delta$ and $\varepsilon$ ). ${ }^{6}$ The B-subunit has no known enzymatic activity, but it does increase the intracellular concentration and nuclear translocation of DNA polymerase $\alpha$ and is phosphorylated by cdk2/cyclin E or cdk2/cyclin A in a cell cycledependent manner. ${ }^{6-10}$ It might also help to tether the pol $\alpha$-primase complex to the origin of replication via interactions with other proteins bound from the pre-initiation complex.

An interesting feature of archaea is sequence information suggesting that they could contain both DnaG-like ${ }^{11}$ and eukaryotic-like DNA primases. The latter consists of two subunits that share significant similarities with the $\mathrm{p} 49 / \mathrm{p} 58$ subunits of the pol $\alpha$-primase complex, ${ }^{12-16}$ whereas no homologues of the p180 and p70 subunits have been found in archaeal genomes. In Euryarchaea, the small (p41) subunit contains the primase catalytic core and can synthesize RNA in Methanococcus jannaschii and Pyrococcus furiosus. ${ }^{13,17}$ Moreover, the $P$. furiosus small subunit alone preferentially uses deoxynucleotides, thus synthesizing up to several kilobases of DNA. ${ }^{17}$ The addition of the large, non-enzymatic, subunit (p46) stabilizes and modulates the activity of the smaller one by increasing the rate of DNA synthesis, reducing the length of the newly synthesized DNA fragments and conferring RNA synthesis capability. ${ }^{14,15}$ RNA-primed replication intermediates, similar to those observed in eukaryotic Okazaki fragments, have been observed in Pyrococcus abyssi and Sulfolobus acidocaldarius, ${ }^{18}$ arguing for the synthesis of RNA or RNA-DNA primers. Because no homologue of DNA polymerase $\alpha$ has been detected in archaeal genomes and 
archaeal primase can synthesize RNA and DNA, it has been suggested that archaeal primase could have both primer synthesis and elongation functions. However, the P. abyssi DNA polymerase $\mathrm{D}$ could also be implicated in the elongation function because it can elongate RNA primers. ${ }^{19}$ The dual potentiality of the archaeal primase is not restricted to Euryarchaea; Sulfolobus solfataricus DNA primase synthesizes RNA and DNA strands up to 1 and $7 \mathrm{~kb}$, respectively. ${ }^{16}$ However, the $S$. solfataricus primase has been shown to display a significantly higher affinity for ribo- than for deoxyribonucleotides; therefore, it was assumed to be more likely to use NTPs,${ }^{16}$ considering the respective intracellular dNTP and NTP concentrations. ${ }^{20}$

Interestingly, sequence and structure similarities have been observed between DNA primases and the family X DNA polymerases, arguing for similar catalytic mechanisms. ${ }^{12,21,22}$ To date, five members of the pol X family have been described in mammalian cells: Pol $\beta$, Pol $\lambda$, Pol $\mu$, Pol $\sigma$ and terminal deoxynucleotidyl transferase. These enzymes play various roles in DNA replication, repair and recombination processes. ${ }^{23}$ In light of the absence of a functional DNA pol X in most archaeal species, it is tempting to speculate that archaeal primase could also be involved in DNA repair. This hypothesis is reinforced by the fact that $S$. solfataricus DNA primase displays a terminal nucleotidyl transferase activity ${ }^{16,24}$ like that of human Pol $\mu$ and Pol $\lambda .^{25,26}$

We report in this study the biochemical characterization of the P. abyssi DNA primase and show that the heterodimeric complex is necessary for archaeal survival. The enzyme can synthesize in vitro both RNA and DNA fragments up to 150 and 3000 bases, respectively. Moreover, we demonstrate that the small subunit alone, or in complex with the large subunit, displays DNA polymerase, gap-filling and strand displacement activities. We propose that in addition to a role in DNA priming, archaeal primases could have an additional role in DNA repair. 


\section{Results}

\section{Purification of the $P$. abyssi DNA primase subunits}

Analysis of the P. abyssi complete genome sequence (available at http://www-archbac.upsud.fr/genomes/newpab/newpab.html) revealed the presence of two genes coding for putative homologues of the two subunits of the eukaryotic type DNA primase (Pab2235 and Pab2236). The arrangement of the primase subunits on the genome is similar to that reported in P. furiosus. ${ }^{14}$ Their predicted products are proteins of 393 and 345 amino acids, respectively, with theoretical molecular masses of 46 and $41 \mathrm{kDa}$, respectively. These two proteins respectively show $75 \%$ and $83 \%$ identity with the large and small subunits of Pyrococcus horikoshii DNA primase. ${ }^{15}$ The two proteins were expressed independently in HMS174 (DE3) E. coli strains. Pabp41 protein, carrying a hexa-histidine tag on the amino terminal region, and the untagged $P a b \mathrm{p} 46$ protein were obtained in the soluble fraction after IPTG induction. Mass spectroscopy analysis of the purified proteins (Figure 1) confirmed their identities (data not shown). The primase subunits were also co-expressed in E. coli and this complex displayed the same properties as p41 and p46 mixed at one to one molar ratio.

\section{$P$. abyssi DNA primase subunits interact in crude cell extracts}

To detect the two DNA primase subunits in P. abyssi cell extracts, polyclonal antibodies raised against the recombinant proteins were used to perform immunoprecipitation experiments. As shown in Figure 2, anti-Pabp41 and anti-Pabp46 antibodies recognized specifically the purified small and large recombinant subunits, respectively (Figure 2, lanes 3 and 4). Moreover, native Pabp41 and Pabp46 in the whole cell extracts were co-precipitated with either anti-Pabp41 or anti-Pabp46 antibodies (Figure 2, lanes 5 and 6). In addition, the interactions between the recombinant $P a b \mathrm{p} 41 / \mathrm{p} 46$ subunits were also observed in coimmunoprecipitation experiments (data not shown). The slightly lower mobility (Figure 2, 
compare lanes 3 and 5) of the recombinant Pabp41 is consistent with the additional Nterminal hexa-histidine tag. These results show that both native and recombinant Pabp41 and Pabp46 form a stable complex. Neither of the two subunits was detected in WCE before immunoprecipitation (Figure 2, lane 7), arguing probably for a small amount of the DNA primase complex in cells.

\section{DNA synthesis capability of the $P$. abyssi DNA primase}

Because the homologous $P$. furiosus DNA primase was shown to preferentially use dNTPs, ${ }^{14,17}$ we first analyzed the DNA synthesis capability of the $P$. abyssi DNA primase. As shown in Figure 3, the primase activity depended on the presence of divalent cations. Under our conditions, extensive dNTP incorporation was detected with 5-10 $\mathrm{mM} \mathrm{MgCl} 2$ and also with $1 \mathrm{mM} \mathrm{MnCl}$ (Figure 3(a)). We also analyzed the DNA synthesis capability of the large and small subunits alone, as compared to the complex, under optimal conditions fixed previously (500 $\mathrm{nM}$ of protein, incubation at $60{ }^{\circ} \mathrm{C}$ during 30 min with $5 \mathrm{mM} \mathrm{MgCl}_{2}$ ). As expected, no incorporation was detected with the large Pabp46 subunit alone, but Pabp41 exhibited a low but significant dNTP incorporation activity (results not shown). To confirm these results and estimate the length of the synthesized fragments, the same experiments were performed using $\left[\alpha^{32} \mathrm{P}\right] \mathrm{dATP}$, instead of $\left[{ }^{3} \mathrm{H}\right] \mathrm{dTTP}$, and the products were resolved on alkaline $1 \%$ agarose gels. Product analysis showed that Pabp46 alone did not have DNA synthesis activity (Figure 3(b), lane 3), but Pabp41 alone could synthesize DNA fragments from 0.2 to $3 \mathrm{~kb}$ in length (Figure 3(b), lane 2). Finally, the addition of the large subunit to the small one drastically increased the rate of DNA synthesis but decreased the length of the DNA fragments to about $0.9 \mathrm{~kb}$ (Figure 3(b), lane 4).

\section{RNA synthesis capability of the $P$. abyssi DNA primase}


To analyze the RNA synthesis capability of Pabp41, Pabp46 and the Pabp41-p46 complex, acid precipitable assays were performed using NTPs containing $\left[{ }^{3} \mathrm{H}\right] \mathrm{UTP}$, and single-stranded circular M13mp18. Unfortunately, the optimal conditions fixed for measuring dNTP incorporation were insufficient to detect NTP incorporation. Because the presence of manganese improves NTP incorporation of the archaeal and eukaryotic primases, ${ }^{13,17,27-29}$ we studied the influence of $\mathrm{Mn}^{2+}$ and $\mathrm{Mg}^{2+}$ concentrations on RNA synthesis capability. Increased $\mathrm{MgCl}_{2}$ concentrations only slightly enhanced NTP incorporation, in contrast to $\mathrm{MnCl}_{2}$ (Figure 3(a)). RNA synthesis of the small and the large subunit alone, compared to the complex, was analyzed in the presence of $\mathrm{MnCl}_{2}$. Neither Pabp46 nor Pabp41 displayed any NTP incorporation activity (results not shown). However, the addition of Pabp46 to the small catalytic subunit conferred the ability to incorporate NTPs but the activity was about twenty times lower that with dNTPs (Figure 3(a)). To confirm these results and analyze the length of the synthesized RNA fragments, product analysis assays were performed using $\left[\alpha^{32} \mathrm{P}\right] \mathrm{ATP}$ instead of $\left[{ }^{3} \mathrm{H}\right] \mathrm{UTP}$, and the products were resolved on denaturing $15 \%$ polyacrylamide gels. As shown in Figure 3(c), RNA synthesis activity was only detectable in the presence of the complex Pabp41-p46, and fragments up to around 150 bases were obtained in the presence of $5 \mathrm{mM} \mathrm{Mn}^{2+}$ (Figure 3(d)). In addition, Pabp41-p46 RNA synthesis depended on the divalent cation, with a drastic decrease in fragment size from 150 to $15-30$ bases with a switch from 5 $\mathrm{mM} \mathrm{MnCl} l_{2}$ to $10 \mathrm{mM} \mathrm{MgCl}$ (Figure 3(c)).

\section{Kinetic experiments}

To determine the affinity of the primase for both NTPs and dNTPs, kinetic experiments were performed. Because the primase displayed different metal ion dependence, these experiments were conducted in the presence of both magnesium and manganese. We first ascertained that adding $\mathrm{Mg}^{2+}$ and $\mathrm{Mn}^{2+}$ simultaneously in the incubation mixtures did not 
inhibit dNTP or NTP incorporation. As shown in Figure 4(a), the presence of the two divalent metal ions improved the incorporation rate of both NTPs and dNTPs, and optimal ion concentrations were fixed at $10 \mathrm{mM} \mathrm{MgCl}_{2}$ and $5 \mathrm{mM} \mathrm{MnCl}_{2}$ for determination of kinetic parameters. With NTPs (in the presence of both $\mathrm{Mg}^{2+}$ and $\mathrm{Mn}^{2+}$ ) and with dNTPs (in the presence of $\mathrm{Mg}^{2+}$ ), the enzyme exhibited Michaelis-Menten kinetics (Figure 4(b), Table 2). However, with both $\mathrm{Mg}^{2+}$ and $\mathrm{Mn}^{2+}$, $\mathrm{dNTP}$ incorporation showed double-Michaelis behavior, indicating two classes of active sites (Figure 4(c), Table 2). Because fitting kinetic data to the double-Michaelis is extremely inaccurate ${ }^{30}$ the data from the double reciprocal plot were fitted to a two-phase linear equation to obtain a rough estimate of the kinetic parameters. In summary, affinity constants were in the same range for NTP and dNTP incorporation, and two types of active sites can be visualized for dNTP incorporation in the presence of both $\mathrm{Mg}^{2+}$ and $\mathrm{Mn}^{2+}$ (Table 2).

\section{Primer-elongation activity of $P$. abyssi DNA primase}

Our results showed that $P$. abyssi DNA primase displays an in vitro capability to incorporate ribonucleoside triphosphate and deoxyribonucleoside triphosphate. Therefore, the primer elongation activity of $P$. abyssi DNA primase (Pabp41-p46) and the Pabp41 subunit was analyzed in the presence of fluorescein-5'-end-labeled DNA or RNA primers hybridized to a short single-stranded DNA template of 87 bases. As shown in Figure 5(a) and (b), Pabp41 as well as the Pabp41-p46 complex were able to elongate both DNA and RNA primers up to 87 bases. Nevertheless, the elongation efficiency was higher with the Pabp41p46 complex because the $87-$ mer products were obtained with 0.625 pmol of Pabp41-p46 complex, whereas $2.5 \mathrm{pmol}$ of $\mathrm{Pabp} 41$ was required to obtain comparable results. Similar results were obtained with the RNA primers (data not shown). The elongation of the same primers, hybridized to single-stranded circular M13mp18 DNA, was also analyzed. Because 
no signal was obtained with the 5 ' -end-fluorescein RNA primer, we used 5 ' - end- $\left[{ }^{32} \mathrm{P}\right]$ primers. Pabp41 as well as the Pabp41-p46 complex could elongate the DNA or RNA primer to the same extent (Figure 5(b)): respectively $0.2-3 \mathrm{~kb}$ for Pabp41 and $0.2-0.9 \mathrm{~kb}$ for the complex. The same results were observed with 5'-end-fluorescein DNA primer (data not shown). Taking these results together, we can propose that the $P$. abyssi primase behaves like a DNA polymerase implicated in RNA primer elongation function and/or in repair-synthesis mechanisms in view of the pol $\mathrm{X}$ connection.

\section{Gap-filling and strand-displacement activities of $P$. abyssi DNA primase}

To assess the possible implication of the archaeal DNA primase in repair-synthesis mechanisms, we analyzed the capability of the $P$. abyssi DNA primase to engage in gapfilling and strand-displacement activities. We used the short, single-stranded DNA template of 87-mer, hybridized to DNA upstream and either RNA or DNA downstream primers (Figure 6(a)), with a defined gap of $25 \mathrm{nt}$. The incubation conditions were the same as earlier described for P. abyssi DNA polymerases B and D. ${ }^{19}$ Template 1 without the downstream primer served as a control. Gap-filling activity resulted in the synthesis of 57-nt fragments, and longer fragments reflected a strand-displacement activity. As shown in Figure 6(a) (template 1), both Pabp41 and Pabp41-p46 elongated DNA primers up to 87 bases. 87-mer products were also obtained with the 25-nt DNA-DNA or DNA-RNA gap template either with the Pabp41 or the Pabp41-p46 complex (Figure 6(a), templates 2 and 3). However, the elongation efficiency was reduced: twice as much enzyme was required to obtain similar profiles compared to that obtained in the absence of a downstream primer (data not shown). Also, no degradation of the upstream and downstream primers were observed which excluded contamination by a nuclease and $5^{\prime} \rightarrow 3^{\prime}$ as well as $3^{\prime} \rightarrow 5^{\prime}$ exonuclease activity. These results show that Pabp41 and Pabp41-p46 complex could displace DNA or RNA downstream 
primers after completion of a 25-nt gap. Also, as previously reported, ${ }^{19}$ P. abyssi DNA

polymerase B displayed no strand displacement activity under the same conditions (data not shown). The same results were obtained with a DNA-DNA gap of either 1 or $10 \mathrm{nt}$ (data not shown).

In addition, the experiments were also repeated on a single-stranded circular M13mp18 template hybridized to the primers described in Figure 6(a). Like with the 87 template, Gapfilling activity resulted in the synthesis of 57-nt fragments and longer fragments reflected a strand-displacement activity. In the presence of a 25-nt DNA-DNA or DNA-RNA gap, Pabp41 and the Pabp41-p46 complex also could elongate the upstream primers up to 87 and 100 nt, respectively (Figure 6(b), templates 6 and 7), showing that Pabp41 and Pabp41-p46 can fill the gap and displace 30 to 50 bases of DNA or RNA. We also analyzed the elongation of the upstream primer in the absence of gap with nick-templates (Figure 6(a) and (b), templates 4 and 8 ). In that cases all fragments up to the 32 primer bases reflected a stranddisplacement activity. Pabp41 and Pabp41-p46 could elongate the upstream primer up to 87 bases on the 87 template (Fig 6A template 4) and to at least 57 bases on the M13 template (Fig 6B, template 8). These results confirmed the $P$. abyssi DNA primase was able to displace around 25 to 55 bases.

We also analyzed the effect of a downstream 3'-end, biotinylated DNA primer that cannot be elongated but only displaced. Under this condition, the upstream primer was elongated to the same extent as that achieved without a downstream primer, showing that the entire 30 base primer was displaced after completion of the gap (data not shown). Therefore, our results show that $P$. abyssi DNA primase can fill gaps from 1 to $25 \mathrm{nts}$ and displace DNA or RNA primers up to 50 -mer.

\section{In Haloferax volcanii, dnaG is not essential, contrary to the eukaryotic-like primase}


In view of all these results, the eukaryotic-like DNA primase in archaea displays a wide range of catalytic activities and is likely to play a key role in archaeal DNA replication and/or repair. However, archaea also possess a DnaG-like protein with similarity to bacterial primase. Because efficient genetic tools have not been developed for Pyrococcus species, we attempted inactivation of a corresponding gene in the halophilic Euryarchaea Haloferax volcanii. At first, analysis of the preliminary genome sequence of $H$. volcanii (Hartman et al., in preparation) using TBLASTN allowed the identification of homologues of both eukaryotic PriS and PriL primase subunits and bacterial DnaG, as commonly found in archaea. Then, we deleted the DnaG gene (promoter and ORF, Figure 7(B)) from strain H53 using the popin/pop-out procedure ${ }^{31,32}$ with replacement of the gene of interest by the $\operatorname{trp} \mathrm{A}$ marker. No polar effects were expected because the $d n a G$ gene is not part of an operon. After integration of the vector upstream or downstream from the region to be deleted (pop-in), the cells were grown in the absence of selective pressure to allow plasmid excision (pop-out), which can either retrieve the wild-type configuration $\left(5 \mathrm{FOA}^{\mathrm{R}} \operatorname{trp}\right)$ or lead to a deletion event $\left(5 \mathrm{FOA}^{\mathrm{R}}\right.$ $\left.\operatorname{trp}^{+}\right)$. Pop-out cells represented around 5\% of total culture; half were trp ${ }^{+}$and thus corresponded to putative deletion mutants. PCR reactions confirmed the replacement of the $d n a \mathrm{G}$ gene by the $\operatorname{trp} \mathrm{A}$ marker, indicating that the $d n a \mathrm{G}$ is not essential under laboratory conditions.

Subsequently, the trpA marker was removed by a new pop-in/pop-out, as described earlier in the Materials and Methods section, to make the deletion mutant strain CN21. The effective loss of the sequence containing the $d n a \mathrm{G}$ gene was confirmed by PCR, as shown in Figure 7(C) and (D). Strain CN21 did not present any obvious growth defect under laboratory conditions. Subsequently and using the same procedure, we tried to delete from the strains H53 and CN21 ( $\triangle d n a G)$ the priS or priL genes that encode the two subunits of the eukaryoticlike primase. After the pop-out, only a few CFU (in each case less than 10 over $10^{7}$ plated 
cells) presented the expected $5 \mathrm{FOA}^{\mathrm{R}} \operatorname{Trp}^{+}$phenotype corresponding theoretically to the deletion event. These colonies were tested for the absence of the gene of interest and presented the same negative result (Figure 7(C) and (D)). For each, the plasmid was still integrated into the chromosome, and the $5 \mathrm{FOA}^{\mathrm{R}}$ was most certainly the result of a mutation in the pyrE2 gene. This outcome indicates a $10^{-6}$ spontaneous mutation rate in this system. These results suggest that in $\mathrm{H}$. volcanii, genes coding for each subunit of the eukaryotic-like primase (priS and priL) are essential, although the $d n a G$ gene is dispensable for cell growth. Thus, priS and priL might code for the actual replicative primase and DnaG may play only a dispensable role, if any, during DNA replication processes. 


\section{Discussion}

Archaea, with their circular chromosomes, the organization of their genes into operons, and their lack of introns and a nucleus, appear very similar to Bacteria. However, analysis of archaeal genomes has revealed that their DNA replication machinery is more similar to that of eukaryotes. Interestingly, both bacterial (DnaG-like) and eukaryotic-like DNA primase genes have been identified in archaeal genomes. A detailed characterization of the DnaG-like protein has not been yet performed. In S. solfataricus, the DnaG-like protein was found to be associated with the exosome-like complex, suggesting its involvement in RNA metabolism in this species. ${ }^{33}$ In contrast, the eukaryotic-like DNA primase was investigated in several archaeal species ${ }^{13-17,24}$ and was shown to interact with RPA in P. furiosus, arguing for its involvement in the archaeal replisomes. ${ }^{17}$ Nevertheless, the in vivo role of both putative primases has not been determined. We show in this paper that, in contrast to the DnaG-like protein, the presence of both subunits of the eukaryotic-like DNA primase is essential for archaeal cell survival. Because the primase activity is essential for cell division, our results show that the eukaryotic-like DNA primase subunits are likely implicated in the crucial initiation process of DNA replication.

We have analyzed the biochemical properties of the $P$. abyssi DNA primase. The $P$. abyssi small subunit alone had no RNA synthesis activity but could synthesize long DNA strands (up to $3 \mathrm{~kb}$ ). The addition of the p46 subunit drastically changed the enzymatic activity, increasing the rate of DNA synthesis while decreasing the length of the DNA fragments and conferring RNA synthesis capability, as already observed in $P$. furiosus. This work confirms that the euryarchaeal primase small subunit contains the catalytic core and that the large subunit modulates its activity like its eukaryotic counterpart. ${ }^{3}$ Moreover, our results suggest that all archaeal DNA primases may display RNA and DNA synthesis activity. ${ }^{14-16}$ Since archaea don't possess a homologue of the eukaryal primase/DNA polymerase complex, 
it is tempting to speculate that archaeal primases could fulfill both primer synthesis and extension functions. In accordance with this idea, our results show that the $P$. abyssi DNA primase displays DNA polymerase activity, with the ability to elongate RNA or DNA primers. However, the polymerase activity of the archaeal primase could possibly be involved in processes other than priming. Indeed, the sequence and structure similarities of this enzyme with the family of X DNA polymerases ${ }^{21,22}$ suggest that archaeal DNA primase could play a role in DNA repair. In agreement with this hypothesis, we have shown, for the first time, that P. abyssi DNA primase displays gap-filling and strand-displacement activities, as do Pol $\beta$ and $\lambda .^{23,34}$ Therefore, the primase could fulfill the role of the DNA pol X, a family that has until now not been detected in Pyrococcus.

The multiple capabilities of the archaeal DNA primase leads to an important question: What is the nature of the primer synthesized in archaea? To address this question, we have analyzed the affinity of the $P$. abyssi DNA primase for ribo- and deoxyribonucleotides. In our experimental conditions, the $\mathrm{Km}$ value for ribonucleotides was $27 \mu \mathrm{M}$, which is identical to that described for $S$. solfataricus DNA primase ${ }^{16}$ and also in the range observed for the eukaryotic (8 to $175 \mu \mathrm{M})$ and bacterial (30 to $50 \mu \mathrm{M})$ primases. ${ }^{3,35}$ Nevertheless, in contrast to S. solfataricus DNA primase, we found that the $\mathrm{Km}$ value for the $P$. abyssi homolog is quite similar for ribo- and deoxyribonucleotides. Thus, in vivo, the DNA primase substrate choice must depend on the intracellular concentration of NTPs and dNTPs.

Unfortunately, however, information about archaeal intracellular NTP and dNTP pools is not available. In mammalian cells, the average concentrations are approximately $0.3-3.1 \mathrm{mM}$ NTPs and 5-37 $\mu \mathrm{M}$ dNTPs. ${ }^{20}$ In such a context, the P. abyssi DNA primase would probably preferentially use ribonucleotides and synthesize an RNA primer. This suggestion is in accordance with the discovery in $P$. abyssi of RNA-primed replication intermediates similar to those observed in eukaryotic Okazaki fragments. ${ }^{18}$ However, it does not exclude that 
archaeal primase could synthesize pre-Okazaki fragments composed of RNA-DNA primers, as does the eukaryotic pol $\alpha$-primase complex. In that case, modifications of DNA primase behavior must occur when the defined length of an RNA primer is obtained and could explain the switch from ribonucleotides to deoxyribonucleotides. Such a hybrid primer would be extended afterward by replicative DNA polymerases.

It is also possible, however, that the elongation function could be achieved by the DNA polymerase D, which also can elongate RNA primers. ${ }^{19}$ In the latter case, a competition could occur between the primase and DNA polymerase D for the 3'-end of the RNA primer. Therefore, the role of other replication factors in the switch between the two enzymes requires further study. The implication of RF-C (replication factor C) could be particularly important because this factor influences primer synthesis and has been implicated in the switch between the pol $\alpha$ primase complex and replicative DNA polymerases in humans. ${ }^{36,37}$ Moreover, an interaction between RF-C and DNA primase in $S$. solfataricus has been recently described. This interaction modulates the activities of both enzymes and may be involved in the regulation of primer synthesis and the transfer of primers to DNA polymerase. ${ }^{38}$

Because Okazaki fragments in P. abyssi were at about 120 bases with a short (around 10 nucleotides) RNA primer, ${ }^{18}$ another question arises: What is the physiological relevance of the remarkably long RNA (150 bases) and DNA (900 bases) products obtained in vitro? As shown previously, the $P$. abyssi primase activity not only depends on the presence of divalent cations, but also the metal ion composition can direct enzymatic activities. Thus, the primase can synthesize around 150-base RNA products in the presence of $5 \mathrm{mM} \mathrm{Mn}^{2+}$, but in the presence of $10 \mathrm{mM}$ of $\mathrm{Mg}^{2+}$, the rate of RNA synthesis drastically decreases to about $15-30$ bases of RNA. Moreover, we showed that dNTP incorporation follows double-Michaelis behavior in the presence of $\mathrm{Mg}^{2+}$ and $\mathrm{Mn}^{2+}$, whereas a simple Michaelis-type behavior is observed in the presence of $\mathrm{Mg}^{2+}$ alone. This finding suggests that the archaeal DNA primase 
enzymatic activity specificities depend on the buffer composition. The same dependence has been observed for the human DNA primase: it was shown that $\mathrm{Mn}^{2+}$ binds and stimulates the primase by decreasing the Km value for NTPs. ${ }^{27}$

Thus, the determination of the intracellular composition in archaea would be extremely useful in understanding the in vivo activities of the archaeal DNA primase and would contribute to understanding more precisely the length and composition of the primers synthesized. It is also possible that, in vivo, other factors are required to modulate the synthesis capability of the DNA primase. For example, in E. coli, the size of the nascent primer synthesized by DnaG is regulated by its interaction with DNA polymerase III and DnaB. ${ }^{4,35}$ Following these clarifications, extensive searches for proteins that interact with the archaeal DNA primase would likely contribute to a better understanding of the archaeal priming process. 


\section{Acknowledgements}

This work was supported by grants from the European Union through the REPBIOTECH program (contract number QLK3-CT-2002-02071). We thank the proteomics core facility at OUEST-genopole ${ }^{\circledR}$ and M. Régis Lavigne for valuable technical assistance. D.F. was financially supported by the French National Institute of Marine Genomics (contract number: FNS-500-370). 


\section{Materials and methods}

\section{Chemicals and enzymes}

Radiolabeled nucleotides, Microspin ${ }^{\mathrm{TM}}$ G-25 and single-stranded circular M13mp18 were purchased from Amersham Biosciences (Saclay, France); unlabeled dNTPs and NTPs from Roche Applied Science (Meylan, France); T4 polynucleotide kinase and restriction enzymes from NEB (Ipswich, MA, USA); Pfu DNA polymerase from Promega (Charbonnières, France); and fluorescein maleimide derivative (5' -end Tag Nucleic Acid Labeling System) from Vector Laboratories (Burlingame, CA, USA). All other reagents were of analytical grade and purchased from Sigma-Aldrich (St. Louis, MO, USA) or MP Biomedicals (Illkirch, France).

\section{Cloning of Pab2235 and Pab2236}

The primase genes were amplified from P. abyssi genomic DNA by PCR, using Pfu or Taq DNA polymerase. The primers Pabp41-for (5'-

GAGGGAAGGTACCATGCTTCTAAGGGAGGT-3') and Pabp41-rev (5'AGGGCAAGCTTCTAAAAGTTCTCTTCGAGG-3') for Pab2236 and Pabp46-for (5'TAGTAGgtATACATATGCTCGATCCATTCAG-3') and Pabp46-rev (5'GCTTGGCAGTCGACTCATTGCTGTAGAACTC-3') for Pab2235, contained Kpn I and Hind III (Pab2236) and Nde I and Sal I (Pab2235) restriction sites respectively. The PCR products were cloned into a TOPO BLUNT vector (Invitrogen, Cergy Pontoise, France) and pGEM-T vector (Promega) to create the Topo-Blunt-Pab2236 and pGEM-T-Pab2235 constructs, respectively. After confirmation of the nucleotide sequence, the constructs were respectively digested by KpnI/HindIII and NdeI/SalI. The products were cloned into the KpnI/HindIII-linearized E. coli expression vector pQE80L (Qiagen, Courtaboeuf, France) or into the NdeI/SalI-linearized E. coli expression vector pET26b(+) (Novagen, San Diego, CA, 
USA), respectively, to create pQE-Pab2236 and pET26-Pab2235 constructs and to produce a Pabp41 protein containing a hexa-histidine tag at the N-terminus and an untagged Pabp46 protein.

\section{Expression and purification of $P a b p 41$ and $P a b p 46$}

The E. coli HMS 174 cells, transformed with pQE-Pab2236 or pET26-Pab2235 plasmids, were grown at $37^{\circ} \mathrm{C}$ in LB medium supplemented with ampicillin or kanamycin, respectively. When the absorbance at $600 \mathrm{~nm}$ reached $0.6,1 \mathrm{mM}$ isopropyl- $\beta-\mathrm{D}$ thiogalactopyranoside (IPTG) was added to induce expression of the Pabp41 and Pabp46 proteins, respectively. After an overnight incubation at $37^{\circ} \mathrm{C}$, cells were harvested by centrifugation. The pellets were resuspended in buffer A1 (20 mM Tris- $\mathrm{HCl} \mathrm{pH} 8,1 \mathrm{mM}$ DTT, 20 mM imidazole) for Pabp41 or A2 (50 mM Tris-HCl pH 8, 1 mM DTT) for Pabp46, supplemented with the "Complete Protease Inhibitor Cocktail" (Roche Applied Science). Cell disruption occurred by three consecutive passages through a French press apparatus. The resulting lysates were centrifuged for $45 \mathrm{~min}$ at $14,000 \times \mathrm{g}$ at $4{ }^{\circ} \mathrm{C}$. The supernatants were incubated twice at $80{ }^{\circ} \mathrm{C}$ for $20 \mathrm{~min}$ to remove most of the E. coli proteins, filtered through a $0.22-\mu \mathrm{m}$ filter (Millipore) and subjected to chromatography.

For Pabp41, the supernatant was loaded onto a 5-ml HisTrap ${ }^{\mathrm{TM}}$ (Amersham Biosciences) connected to an FPLC apparatus (Amersham Biosciences). The chromatograph was developed with a $135-\mathrm{ml}$ gradient of $0.02-1 \mathrm{M}$ imidazole in $20 \mathrm{mM}$ Tris- $\mathrm{HCl} \mathrm{pH} 8,1 \mathrm{mM}$ DTT, at a flow rate of $1 \mathrm{ml} / \mathrm{min}$. The fractions containing Pabp41 were pooled and dialyzed against $20 \mathrm{mM}$ Tris-HCl pH 8, $0.5 \mathrm{mM}$ EDTA, $150 \mathrm{mM} \mathrm{NaCl}, 1 \mathrm{mM}$ DTT and 50\% (v/v) glycerol and stored at $-20^{\circ} \mathrm{C}$.

For Pabp46, the supernatant was loaded onto an anion exchange column HiPrep Q XL $(1.6 \times 10 \mathrm{~cm}$, Amersham Biosciences $)$ connected to an FPLC apparatus. The elution was 
performed with a gradient of $\mathrm{NaCl}(0-1 \mathrm{M})$ at a flow rate of $1 \mathrm{ml} / \mathrm{min}$ in $50 \mathrm{mM}$ Tris- $\mathrm{HCl} \mathrm{pH}$ 8, $1 \mathrm{mM}$ DTT. The fractions containing Pabp46 were pooled and dialyzed against $20 \mathrm{mM}$ Tris-HCl pH 8, 1 mM DTT. The sample was then loaded to a mono Q column (HR10/16 Amersham Biosciences). The chromatograph was developed with a 35-ml gradient of 0-1 M $\mathrm{NaCl}$ in $50 \mathrm{mM}$ Tris- $\mathrm{HCl} \mathrm{pH} 8,1 \mathrm{mM}$ DTT at a flow rate of $0.5 \mathrm{ml} / \mathrm{min}$. The collected fractions containing Pabp46 were applied to a Superdex 200 gel filtration column (Amersham Biosciences) pre-equilibrated in $20 \mathrm{mM}$ Tris- $\mathrm{HCl} \mathrm{pH} 8,1 \mathrm{mM}$ DTT, 10\% (v/v) glycerol at a flow rate of $1 \mathrm{ml} / \mathrm{min}$. The fractions containing Pabp46 were pooled and dialyzed against 20 mM Tris- $\mathrm{HCl} \mathrm{pH}$ 8, $0.5 \mathrm{mM}$ EDTA, $150 \mathrm{mM} \mathrm{NaCl}, 1 \mathrm{mM}$ DTT, 50\% (v/v) glycerol and stored at $-20^{\circ} \mathrm{C}$.

To form the p41-p46 complex, Pabp41 and Pabp46 were mixed at one to one molar ratio before use.

\section{Immunoprecipitation experiments}

Whole-cell extracts (WCE) from P. abyssi GE5 ${ }^{39}$ were made from approximately 2100 cells $/ \mathrm{ml}$ according to the methods described in. ${ }^{40}$ The protein concentration of the extract was $20 \mu \mathrm{g} / \mu \mathrm{l}$ in the extraction buffer (20 mM HEPES-KOH pH 7.9, $1.5 \mathrm{mM} \mathrm{MgCl} 2,0.42 \mathrm{M} \mathrm{NaCl}$, $1 \mathrm{mM}$ DTT, $0.5 \mathrm{mM}$ phenyl methyl sulfonyl fluoride and 25\% (v/v) glycerol). Dynabeads Protein A (Dynal Biotech, Oslo, Norway) were equilibrated with buffer A3 (0.1 M Naphosphate $\mathrm{pH} 8,100 \mathrm{mM} \mathrm{NaCl}$ and $0.01 \%$ Tween 20) and incubated with either a purified anti-Pabp46 or anti-Pabp41 polyclonal antibody (Eurogentec, Seraing, Belgium) at a ratio of about $2.5 \mu \mathrm{g}$ of antibody per $1 \mu \mathrm{l}$ of beads for $30 \mathrm{~min}$ at room temperature with gentle shaking. After extensive washing with the same buffer, WCE (1 mg) were added to the beads, and incubation followed for $1 \mathrm{~h}$ at $4{ }^{\circ} \mathrm{C}$. After three washes with buffer A3, beads were suspended in SDS-PAGE loading buffer (50 mM Tris-HCl pH 6.8, 2 mM EDTA, $1 \%$ (w/v) $\beta$ - 
mercaptoethanol, $8 \%$ (v/v) glycerol and $0.025 \%$ (w/v) bromophenol blue). Proteins were separated on $12 \%$ SDS-polyacrylamide gels and transferred to a polyvinylidene fluoride membrane (Bio-Rad) and probed with either rabbit anti-Pabp46 or anti-Pabp41, followed by goat anti-rabbit IgG-horseradish peroxidase and Enhanced ChemiLuminescence (Amersham Biosciences).

\section{Nucleic acid substrates}

Oligonucleotides were synthesized and purified by Eurogentec. The 5'-end fluorescein-labeled primers were purchased from Eurogentec for the DNA upstream primer (U-DNA p) or produced as described: Primers (150 pmol) were incubated with ATP- $\gamma-\mathrm{S}$ (750 nmol), T4 polynucleotide kinase (1-2 units) in $1 \times \mathrm{T} 4 \mathrm{PNK}$ buffer for $30 \mathrm{~min}$ at $37{ }^{\circ} \mathrm{C}$ according to the 5'-end labeling kit (Vector Laboratories). Fluorescein maleimide was then added and the mixture incubated at $65{ }^{\circ} \mathrm{C}$ for $30 \mathrm{~min}$. For determination of DNA polymerase activity on M13mp18, $\left[\gamma_{-}{ }^{32} \mathrm{P}\right]$ ATP was used instead of ATP- $\gamma-\mathrm{S}$ and fluorescein to obtain a higher signal. In the ${ }^{32} \mathrm{P}$ labeling method, primers $(100 \mathrm{pmol})$ were incubated for 30 min at $37^{\circ} \mathrm{C}$ with $[\gamma$ $\left.{ }^{32} \mathrm{P}\right] \mathrm{ATP}(3 \mu \mathrm{Ci})$ with $1-2$ units of T4 PNK. In all cases, reactions were carried out in a total volume of $30 \mu \mathrm{l}$ and free $\left[\gamma_{-}{ }^{32} \mathrm{P}\right] \mathrm{ATP}, \mathrm{ATP}-\gamma-\mathrm{S}$ and fluorescein were removed on Microspin ${ }^{\mathrm{TM}}$ G-25 columns. The gapped and primed DNA templates were prepared as described in. ${ }^{19}$ The sequences of the oligonucleotides used in this work were: U-DNA p (upstream-DNA primer) 5'-TGCCAAGCTTGCATGCCTGCAGGTCGACTCTA-3'; U-RNA p (upstream-RNA primer) 5'-UGCCAAGCUUGCAUGCCUGCAGGUCGACUCUA-3'; D-DNA p (downstream-DNA primer) 5'-ATTCGTAATCATGGTCATAGCTGTTTCCTG-3'; D-RNA p (downstream-RNA primer) 5' - AUUCGUAAUCAUGGUCAUAGCUGUUUCCUG-3'; DNick-DNA p (downstream-Nick-DNA primer) 5'- GAGGATCCCCGGGTACCGAGCTCGA 
ATTCGTAATCATGGTCATAGCTGTTTCCTG-3'. L87 (87 single-stranded linear DNA template) was described previously. ${ }^{19}$

\section{Primase assays: RNA and DNA synthesis without primers}

Acid-precipitable assay

Reaction mixtures $(10 \mu \mathrm{l})$ containing assay buffer $(50 \mathrm{mM}$ Tris- $\mathrm{HCl} \mathrm{pH} 8,1 \mathrm{mM} \beta$ mercaptoethanol), $7.5 \mathrm{nM}$ M13mp18 single-stranded circular DNA template and $0.5 \mu \mathrm{M}$ of Pabp41, Pabp46 or Pabp41-p46 complex and $\mathrm{MgCl}_{2}$ or $\mathrm{MnCl}_{2}$ as indicated in the figures, were incubated with either $100 \mu \mathrm{M}$ NTPs containing $\left[{ }^{3} \mathrm{H}\right] \mathrm{UTP}(0.8 \mu \mathrm{Ci})$ for RNA synthesis, or $100 \mu \mathrm{M}$ dNTPs containing $\left[{ }^{3} \mathrm{H}\right] \mathrm{dTTP}(0.8 \mu \mathrm{Ci})$ for DNA synthesis, for $30 \mathrm{~min}$ at $60{ }^{\circ} \mathrm{C}$ and then kept on ice. The products obtained were precipitated with $10 \%$ (w/v) TCA, and insoluble radioactive materials were determined by scintillation counting. The average of three measurements was taken and expressed as a percentage of the maximal value obtained in each experiment.

\section{Product analysis}

The reaction was performed as described above except that $0.3 \mu \mathrm{Ci}$ of $\left[\alpha-{ }^{32} \mathrm{P}\right](\mathrm{d}) \mathrm{ATP}$ replaced tritiated nucleotides. The reactions were carried out for $30 \mathrm{~min}$ at $60{ }^{\circ} \mathrm{C}$, and samples were quenched on ice by addition of one volume of stop buffer (98\% (v/v) formamide, 10 mM EDTA). Samples were incubated for $10 \mathrm{~min}$ at $100^{\circ} \mathrm{C}$. The RNA products were separated on precast denaturing $15 \%$ polyacrylamide gels (Bio-Rad, Ivry sur Seine, France) and the DNA products on denaturing alkaline $1 \%(\mathrm{w} / \mathrm{v})$ agarose gels. Visualization of products was performed after scanning the gels with a phosphorimager. RNA ladder or a $1 \mathrm{~Kb}$ Plus DNA Ladder (Invitrogen) was radiolabeled with T4 polynucleotide kinase and used as the molecular mass marker. 


\section{Steady-state kinetics}

All reactions were carried out in a total volume of $10 \mu \mathrm{l}$ with $0.15-0.5 \mu \mathrm{M}$ primase complex in $50 \mathrm{mM}$ Tris- $\mathrm{HCl} \mathrm{pH} 8,1 \mathrm{mM} \beta$-mercaptoethanol, $\mathrm{MnCl}_{2}$ and $\mathrm{MgCl}_{2}$, as indicated in the figure legends, and either $\left[{ }^{3} \mathrm{H}\right] \mathrm{dTTP}(0.2 \mu \mathrm{Ci})$ or $\left[{ }^{3} \mathrm{H}\right] \mathrm{UTP}(0.2 \mu \mathrm{Ci})$. The amount of the M13mp18 single-stranded circular DNA template was kept constant (7.5 nM), and the concentration of dNTPs or NTPs was 1 to $500 \mu \mathrm{M}$. The reactions were performed at $60{ }^{\circ} \mathrm{C}$ for 5-10 min and kept on ice. Products obtained were precipitated with 10\% (w/v) TCA, and insoluble radioactive materials were determined by scintillation counting. The average of three measurements was calculated for each point. Standard curves for $\left[{ }^{3} \mathrm{H}\right] \mathrm{dTTP}$ and $\left[{ }^{3} \mathrm{H}\right] \mathrm{UTP}$ were used to convert the counts per minute to pmoles of product synthesized per minute and per pmol of primase. NTP and dNTP incorporation was determined under steadystate conditions, and the data were first analyzed using the Lineweaver-Burk plot. Then, kinetic constants were obtained by nonlinear regression using the Marquardt-Levenberg algorithm.

\section{Primer elongation and gap-filling assays}

Reaction mixtures $(10 \mu \mathrm{l})$ contained $100 \mu \mathrm{M}$ dNTPs, 0-1 $\mu \mathrm{M}$ Pabp41, Pabp46 or Pabp41-p46 complex in assay buffer (50 mM Tris- $\mathrm{HCl} \mathrm{pH} 8.0,1 \mathrm{mM} \beta$-mercaptoethanol, $5 \mathrm{mM} \mathrm{MgCl}$ ). These reactions were incubated for $30 \mathrm{~min}$ at $60{ }^{\circ} \mathrm{C}$ with $0.125 \mathrm{pmol}$ of linear 87 singlestranded template or 0.04 pmol of single-stranded circular M13mp18 template, previously hybridized with appropriate primers as indicated in the figure legends. The mixtures were kept on ice and stopped by addition of 1 vol of $98 \%$ (v/v) formamide, 10 mM EDTA. Samples were then heated for $10 \mathrm{~min}$ at $100{ }^{\circ} \mathrm{C}$ and products separated on either denaturing $15 \%$ polyacrylamide gels or a denaturing alkaline $1 \%$ agarose gel and subjected to 
phosphorimaging analysis. Labeled $1 \mathrm{~Kb}$ Plus DNA Ladder (Invitrogen) and 87-nt and 57-nt oligonucleotides were used as molecular mass markers.

\section{Gene deletion in Haloferax volcanii}

Gene deletion in $H$. volcanii was carried out using the pop-in/pop-out system. ${ }^{31,32}$ Cells were grown as described $\mathrm{in}^{32}$ in liquid Hv-YPC or solid Hv-Ca media containing either uracil and tryptophan $(50 \mu \mathrm{g} / \mathrm{ml}$ each $)$ or 5-fluoroorotic acid $(50 \mu \mathrm{g} / \mathrm{ml})$ and uracil $(10 \mu \mathrm{g} / \mathrm{ml})$ with or without tryptophan $(50 \mu \mathrm{g} / \mathrm{ml})$. Around $500 \mathrm{bp}$ of genomic regions upstream and downstream from the sequence to be deleted were amplified by PCR using oligonucleotides indicated in Table 1. Half of the internal oligonucleotides could anneal to the $\mathrm{p} f d x:$ trpA marker. The two PCR products were then mixed with the 1-kb BamHI fragment of pTA298 containing $\mathrm{p} f d x:$ trp A marker, and a subsequent PCR using external primers amplified a 2-kb product consisting of $\operatorname{trpA}$ marker flanked by upstream and downstream sequences. The gel-purified 2-kb fragment was then integrated between the XhoI and SpeI sites of pTA131 32 to make pCN30 (priS deletion) and pCN31 (priL deletion) or the XbaI and EcoRI sites to make pAL5 (dnaG deletion). These plasmid constructs were reisolated from E. coli SCS110 [rpsL (Strr) thr leu endA thi-1 lacY galK galT ara tonA tsx dam dcm supE44 $\triangle$ (lac-proAB) $\left[\mathrm{F}^{\prime}\right.$ traD36 proAB lacIqZAM15] ](Stratagene). Transformation using unmethylated DNA from the $H$. volcanii $\Delta p y r E 2 \Delta t r p \mathrm{~A}$ strain H53 was performed as described in. ${ }^{32,41}$ Transformants were selected on Hv-Ca plates lacking uracil and tryptophan then grown without selection for 30 generations and plated on Hv-Ca plates containing either uracil + tryptophan or 5FOA + uracil with or without tryptophan. $5 \mathrm{FOA}^{\mathrm{R}} \operatorname{trp}^{+}$cells were then tested for deletion as indicated in Figure 10. Subsequently, a pAL5 BamHI fragment containing trpA marker was removed to make $\mathrm{pCN} 32$, which was used with pop-in/pop-out to eliminate the trpA marker from the genomic sequence of the $\Delta d n a \mathrm{G}:$ trpA mutant, generating strain $\mathrm{CN} 21(\Delta p y r \mathrm{E} 2 \Delta \operatorname{trp} \mathrm{A}$ 
$\Delta d n a \mathrm{G})$. 


\section{Figure legends}

Figure 1. $P$. abyssi DNA primase: purification of the subunits.

Purification of Pabp46 and Pabp41 subunits. SDS-PAGE (12\%) analysis of the recombinant Pabp41 and Pabp46 proteins at different purification steps; lane 1, supernatant after French press and heat treatment; lane 2, HiPrep 16/10 Q XL or HisTrap HP chromatography; lane 3, MonoQ 5/5 HR chromatography; lane 4, Superdex 200 chromatography.

Figure 2. Interaction of the Pabp46/Pabp41 proteins from $P$. abyssi whole cell extracts (WCEs).

The WCE was immunoprecipitated with either anti-Pabp41 (lane 5) or anti-Pabp46 (lane 6), and the precipitates were detected using the antisera given on the right side. Beads alone (lane 1) or incubated with $20 \mu \mathrm{g}$ of WCE (lane 2), $300 \mathrm{ng}$ of recombinant His-Pabp41 (lane 3) or Pabp46 (lane 4), and $20 \mu \mathrm{g}$ of WCE without immunoprecipitate (lane 7) were loaded as controls.

Figure 3. DNA and RNA synthesis capabilities of the $P$. abyssi DNA primase.

(a) Incorporation of dNTPs containing $\left[{ }^{3} \mathrm{H}\right] \mathrm{dTTP}$ (in white) or NTPs containing $\left[{ }^{3} \mathrm{H}\right] \mathrm{UTP}$ (in black) were incubated in the standard primase assay buffer, for $20 \mathrm{~min}$ at $60^{\circ} \mathrm{C}$, with singlestranded circular M13mp18 DNA template and increasing amounts of either $\mathrm{MgCl}_{2}$ or $\mathrm{MnCl}_{2}$; the amount of radioactivity incorporated was measured in a scintillation counter after TCA precipitation; experiments were performed in triplicate and results are expressed as means \pm SD. (b) DNA priming by the $P$. abyssi DNA primase; single-stranded circular M13mp18 DNA templates were incubated, as indicated in Materials and Methods, with $0.5 \mu \mathrm{M}$ of either Pabp41, Pabp46 or Pabp41-p46 complex, or without any protein as control; $\mathrm{Mg}^{2+}$ was $5 \mathrm{mM}$ and dNTPs containing $\left[\alpha-{ }^{32} \mathrm{P}\right] \mathrm{dATP}$, and the DNA products were resolved on a denaturing alkaline (1\%) agarose gel and visualized using a phosphorimager. (c and d) RNA priming by 
the $P$. abyssi DNA primase; single-stranded circular M13mp18 DNA template was incubated, as indicated in the Materials and Methods, with $0.5 \mu \mathrm{M}$ of either Pabp41, Pabp46, Pabp41p46 complex, or without any protein as control, and NTPs containing $\left[\alpha-{ }^{32} \mathrm{P}\right] \mathrm{ATP} ; \mathrm{Mn}^{2+}$ was $5 \mathrm{mM}$ and RNA products were resolved on a denaturing $15 \%$ polyacrylamide gel (Bio-Rad) and visualized using a phosphorimager.

Figure 4. NTP and dNTP incorporation by $P$. abyssi DNA primase in the presence of both $\mathrm{Mg}^{2+}$ and $\mathrm{Mn}^{2+}$.

(a) M13mp18 single-stranded DNA template was incubated, as indicated in the Material and Methods, with or without $0.5 \mu \mathrm{M}$ of the Pabp41-p46 complex and either dNTPs containing $\left[{ }^{3} \mathrm{H}\right] \mathrm{dTTP}$ or NTPs containing $\left[{ }^{3} \mathrm{H}\right] \mathrm{UTP}$ and with the indicated metal ions. The amount of radioactivity incorporated was measured in a scintillation counter after TCA precipitation and expressed as a percentage of the maximal value. Values are means $\pm \operatorname{SD}(n=3)$.

(b) Steady-state kinetics of the P. abyssi primase with dNTPs, in the presence of $10 \mathrm{mM}$ $\mathrm{MgCl}_{2}$ (closed symbols) and with NTPs, in the presence of $10 \mathrm{mM} \mathrm{MgCl}$ and $5 \mathrm{mM} \mathrm{MnCl} 2$ (open symbols).

(c) Steady-state kinetics of the P. abyssi primase with dNTPs, in the presence of $10 \mathrm{mM}$ $\mathrm{MgCl}_{2}$ and $5 \mathrm{mM} \mathrm{MnCl}_{2}$.

Figure 5. $P$. abyssi DNA primase can elongate RNA or DNA primers.

Primer extension assays were performed with fluorescein-5' -end linear-DNAp (a) (for primer composition, see Table 1) hybridized to the linear 87-nt template in the presence of dNTPs and $0-1 \mu \mathrm{M}$ of either Pabp41 or Pabp41-p46 complex. (b) Primer extension assays were performed with $5^{\prime}-\left[{ }^{32} \mathrm{P}\right]$ end-labeled DNA or RNA primers hybridized to the M13mp18 template in the presence of dNTPs and $0.5 \mu \mathrm{M}$ of either Pabp41, Pabp46 or Pabp41-p46 complex or without any enzyme as control. The extended products were resolved on a 
denaturing $15 \%$ polyacrylamide gel (a) or on a denaturing alkaline (1\%) agarose gel (b) and visualized using a phosphorimager.

Figure 6. $P$. abyssi DNA primase has gap-filling and strand-displacement activities. As outlined in the top of the figure, the DNA templates used were the linear 87-mer DNA (a) or M13mp18 DNA (b) with fluorescein-5' end-labeled upstream DNA primer and downstream DNA or RNA primers to create a 25-nt gap or a nick templates. The assays were performed on these templates, as indicated in the Materials and Methods, with $0.5 \mu \mathrm{M}$ of either Pabp41, Pabp46 or Pabp41-p46 complex or without any enzyme as control. The products were resolved on a 15\% polyacrylamide gel and visualized using a Typhoon 9400 phosphofluorimager.

Figure 7. In Haloferax volcanii, dnaG is not an essential gene but priS and priL deletion events could not be detected.

(A) Diagram presenting the annealing positions of primers used to check for plasmid integration and deletion events in the wild-type, pop-in and deletion mutant pop-out strains (for primer composition see Table 1). PyrE2 and trpA markers are indicated in white boxes. The undulating line corresponds to the integrated plasmid DNA, and the grey boxes indicate the upstream and downstream homology sequences used in the construct. (B) Scaled diagram showing the 1614-base sequence containing the $d n a \mathrm{G}$ gene with its promoter, which was removed in the $\mathrm{CN} 21$ deletion strain. No operon structure could be observed. The ORF1 and ORF2 loci respectively code for a putative sugar phosphate isomerase/epimerase (IolE, COG1082) and a conserved putative transmembrane protein (DUF92, COG1836). (C) Expected sizes of PCR products in base pairs for each deletion attempt. NA refers to No Amplification. Bolded numbers correspond to the agarose gel lanes of panel C. Contrary to dnaG, priS and priL deletion in CN21 was made without the use of the $\operatorname{trpA}$ marker. Also in (D): Agarose gels showing the PCR products obtained for each strain. The PCR products 
presented in lanes 1 to 6 are in agreement with a $d n a G$ deletion. However, products of lanes 9 and 14 indicate that the plasmid has not been removed (pop-out) from the chromosomes of putative priS and priL mutants. The 5FOA resistance is then probably attributable to a mutation in the pyrE2 gene. Accordingly, lanes 11 and 16 indicate that the priS and priL genes are still present. 


\section{References}

1. Woese, C. R., Kandler, O. \& Wheelis, M. L. (1990). Towards a natural system of organisms: proposal for the domains Archaea, Bacteria, and Eucarya. Proc. Natl. Acad. Sci. USA, 87, 4576-4579.

2. Grabowski, B. \& Kelman, Z. (2003). Archaeal DNA replication: Eukaryal proteins in a bacterial context. Ann. Rev. Microbiol. 57, 487-516.

3. Frick, D. N. \& Richardson, C. C. (2001). DNA primases. Ann. Rev. Biochem. 70, 39-80.

4. Zechner, E. L., Wu, C. A. \& Marians, K. J. (1992). Coordinated leading- and laggingstrand synthesis at the Escherichia coli DNA replication fork. III. A polymerase-primase interaction governs primer size. J. Biol. Chem. 267, 4054-4063.

5. Zerbe, L. K. \& Kuchta, R. D. (2002). The p58 Subunit of human DNA primase is important for primer initiation, elongation, and counting. Biochemistry USA, 41, 4891-4900.

6. Arezi, B. \& Kuchta, R. D. (2000). Eukaryotic DNA primase. Trends Biochem. Sci. 25, $572-576$.

7. Foiani, M., Marini, F., Gamba, D., Lucchini, G. \& Plevani, P. (1994). The B subunit of the DNA polymerase alpha-primase complex in Saccharomyces cerevisiae executes an essential function at the initial stage of DNA replication. Mol. Cell. Biol. 14, 923-933.

8. Foiani, M., Liberi, G., Lucchini, G. \& Plevani, P. (1995). Cell cycle-dependent phosphorylation and dephosphorylation of the yeast DNA polymerase alpha-primase B subunit. Mol. Cell. Biol. 15, 883-891.

9. Nasheuer, H., Moore, A., Wahl, A. \& Wang, T. (1991). Cell cycle-dependent phosphorylation of human DNA polymerase alpha. J. Biol. Chem. 266, 7893-7903.

10. Ferrari, M., Lucchini, G., Plevani, P. \& Foiani, M. (1996). Phosphorylation of the DNA polymerase alpha-primase B subunit is dependent on its association with the p180 polypeptide. J. Biol. Chem. 271, 8661-8666. 
11. Aravind, L., Leipe, D. D. \& Koonin, E. V. (1998). Toprim - a conserved catalytic domain in type IA and II topoisomerases, DnaG-type primases, OLD family nucleases and RecR proteins. Nucl. Acids Res. 26, 4205-4213.

12. Kirk, B. W. \& Kuchta, R. D. (1999). Arg304 of human DNA primase is a key contributor to catalysis and NTP binding: primase and the family X polymerases share significant sequence homology. Biochemistry USA, 38, 7727-7736.

13. Desogus, G., Onesti, S., Brick, P., Rossi, M. \& Pisani, F. M. (1999). Identification and characterization of a DNA primase from the hyperthermophilic archaeon Methanococcus jannaschii. Nucl. Acids Res. 27, 4444-4450.

14. Liu, L., Komori, K., Ishino, S., Bocquier, A. A., Cann, I. K., Kohda, D., et al. (2001). The archaeal DNA primase: biochemical characterization of the p41-p46 complex from Pyrococcus furiosus. J. Biol. Chem. 276, 45484-45490.

15. Matsui, E., Nishio, M., Yokoyama, H., Harata, K., Darnis, S. \& Matsui, I. (2003). Distinct domain functions regulating de novo DNA synthesis of thermostable DNA primase from hyperthermophile Pyrococcus horikoshii. Biochemistry USA, 42, 14968-14976.

16. Lao-Sirieix, S. H. \& Bell, S. D. (2004). The heterodimeric primase of the hyperthermophilic archaeon Sulfolobus solfataricus possesses DNA and RNA primase, polymerase and 3'-terminal nucleotidyl transferase activities. J. Mol. Biol. 344, 1251-1263.

17. Bocquier, A. A., Liu, L., Cann, I. K. O., Komori, K., Kohda, D. \& Ishino, Y. (2001). Archeal primase : bridging the gap between RNA and DNA polymerases. Cur. Biol. 11, $452-456$.

18. Matsunaga, F., Norais, C., Forterre, P. \& Myllykallio, H. (2003). Identification of short 'eukaryotic' Okazaki fragments synthesized from a prokaryotic replication origin. EMBO Rep. 4, 1-5. 
19. Henneke, G., Flament, D., Hübscher, U., Querellou, J. \& Raffin, J. P. (2005). The hyperthermophilic euryarchaeota Pyrococcus abyssi likely requires the two DNA polymerases D and B for DNA replication. J. Mol. Biol. 350, 53-64.

20. Traut, T. W. (1994). Physiological concentrations of purines and pyrimidines. Mol. Cell. Biochem. 140, 1-22.

21. Augustin, M. A., Huber, R. \& Kaiser, J. T. (2001). Crystal structure of a DNA-dependent RNA polymerase (DNA primase). Nature Struct. Biol. 8, 57-61.

22. Lao-Sirieix, S.-h., Pellegrini, L. \& Bell, S. D. (2005). The promiscuous primase. Trends Genet. 21, 568-572.

23. Ramadan, K., Shevelev, I. \& Hübscher, U. (2004). The DNA-polymerase-X family: controllers of DNA quality? Nature Rev. Mol. Cell. Biol. 5, 1038-1043.

24. De Falco, M., Fusco, A., De Felice, M., Rossi, M. \& Pisani, F. M. (2004). The DNA primase of Sulfolobus solfataricus is activated by substrates containing a thymine-rich bubble and has a 3'-terminal nucleotidyl-transferase activity. Nucl. Acid Res. 32, 52235230.

25. Dominguez, O., Ruiz, J. F., de Lera, T. L., Garcia-Diaz, M., Gonzales, M. A., Kirchhoff, T., et al. (2000). DNA polymerase mu (Pol $\mu)$, homologous to TdT, could act as a DNA mutator in eukaryotic cells. EMBO J. 19, 1731-1742.

26. Ramadan, K., Maga, G., Shevelev, I. V., Villani, G., Blanco, L. \& Hübscher, U. (2003). Human DNA polymerase $\lambda$ possesses terminal deoxyribonucleotidyl transferase activity and can elongate RNA primers: implications for novel functions. J. Mol. Biol. 328, 63-72.

27. Kirk, B. W. \& Kuchta, R. D. (1999). Human DNA primase: anion inhibition, manganese stimulation, and their effects on in vitro start-site selection. Biochemistry USA, 38, 1012610134. 
28. Santocanale, C., Foiani, M., Lucchini, G. \& Plevani, P. (1993). The isolated 48,000-dalton subunit of yeast DNA primase is sufficient for RNA primer synthesis. J. Biol. Chem. 268, $1343-1348$.

29. Bakkenist, C. \& Cotterill, S. (1994). The 50-kDa primase subunit of Drosophila melanogaster DNA polymerase alpha. Molecular characterization of the gene and functional analysis of the overexpressed protein. J. Biol. Chem. 269, 26759-26766.

30. Bates, J. H., Bates, D. A. \& Mackillop, W. (1987). On the difficulties of fitting the double Michaelis-Menten equation to kinetic data. J. Theor. Biol. 125, 237-241.

31. Bitan-Banin, G., Ortenberg, R. \& Mevarech, M. (2003). Development of a gene knockout system for the halophilic archaeabacteria Haloferax volcanii. J. Bacteriol. 185, 882-778.

32. Allers, T., Ngo, H. P., Mevarech, M. \& Lloyd, R. G. (2004). Development of additional selectable markers for the halophilic archaeon Haloferax volcanii based on the leuB and trpA genes. Appl. Anviron. Microbiol. 70, 943-953.

33. Evguinieva-Hackenberg, E., Walter, P., Hochleitner, E. \& Lottspeich, F. (2003). An exosome-like complex in Sulfolobus solfataricus. EMBO Rep. 4, 889-893.

34. Lebedeva, N. A., Rechkunova, N. I., Dezhurov, S. V., Khodyreva, S. N., Favre, A., Blanco, L., et al. (2005). Comparison of functional properties of mammalian DNA polymerase $\lambda$ and DNA polymerase $\beta$ in reactions of DNA synthesis related to DNA repair. Biochim. Biophys. Acta 1751, 150-158.

35. Corn, J. E. \& Berger, J. M. (2006). Regulation of bacterial priming and daughter strand synthesis through helicase-primase interactions. Nucl. Acids Res. 34, 4082-4088.

36. Mossi, R., Keller, R. C., Ferrari, E. \& Hübscher, U. (2000). DNA polymerase switching: II. Replication factor C abrogates primer synthesis by DNA polymerase $\alpha$ at a critical length. J. Mol. Biol. 295, 803-814. 
37. Maga, G., Stucki, M., Spadari, S. \& Hübscher, U. (2000). DNA polymerase switching: I. Replication factor $\mathrm{C}$ displaces DNA polymerase alpha prior to PCNA loading. J. Mol. Biol. 295, 791-801.

38. Wu, K., Lai, X., Guo, X., Hu, J., Xiang, X. \& Huang, L. (2007). Interplay between primase and replication factor C in the hyperthermophilic archaeon Sulfolobus solfataricus. Mol. Microbiol. 63, 826-837.

39. Erauso, G., Reysenbach, A. L., Godfroy, A., Meunier, J. R., Crump, B., Partensky, F., et al. (1993). Pyrococcus abyssi sp. nov., a new hyperthermophilic archaeon isolated from a deep-sea hydrothermal vent. Arch. Microbiol. 160, 338-349.

40. Godfroy, A., Raven, N. D. H. \& Sharp, R. J. (2000). Physiology and continuous culture of the hyperthermophilic deep-sea vent archaeon Pyrococcus abyssi ST549. FEMS Microbiol. Lett. 186, 127-132.

41. Cline, S. W., Lam, W. L., Charlebois, R. L., Schalkwyk, L. C. \& Doolittle, W. F. (1989). Transformation methods for halophilic archaeabacteria. Can. J. Microbiol. 35, 148-152. 


\begin{tabular}{|c|c|c|c|}
\hline Locus & Position & Primer name & Sequence ( $5^{\prime}$ to $\left.3^{\prime}\right)$ \\
\hline \multirow{9}{*}{ dnaG } & $5^{\prime} \cup p$ & DNAG1X bal & gctctagaCTCGTCGTTCCGTTCCTG \\
\hline & $3^{\prime} \cup p$ & DNAGIBamHI & gtttatccacgggatccGTCTCGTCCCCGAAATCC \\
\hline & 5' Dwn & DNAG2BamHI & acgcacataacggatCCGCAA TCA GTCGA G GAC \\
\hline & 3' Dwn & DNAG2ECORI & ggaattcGCATGA CCGTCGATAGCC \\
\hline & a & OAL 1 & CATGAACTTCGGCATCCA \\
\hline & b & OAL2 & GGATTTCGGGGACGAGAC \\
\hline & c & OAL11 & AAGGTCGGTCGGATAGACG \\
\hline & $d$ & OAL 12 & GAGTTCCCGCAGGATGAGT \\
\hline & e & OAL3 & GTCCTCGACTGATTGCGG \\
\hline \multirow{8}{*}{ pris } & $5^{\prime} \cup p$ & OCN172 & ggactagtGTCCCAGCGGTGAATCTG \\
\hline & $3^{\prime} \cup p$ & OCN173 & gtttatccacgggatccA CA CCTCGGGTTCCGGAG \\
\hline & 5' Dwn & OCN 174 & acgcacataacggatccG GCGTGCA GTCGGTAGAC \\
\hline & $3^{\prime} \mathrm{Dwn}$ & OCN 175 & ccgctcgagA CGA G GTCGTCGA ACA GC \\
\hline & b & OCN215 & GCGGAGACGTAATCGCTTT \\
\hline & c & OCN220 & CGCGAAATCGTGGACTACA \\
\hline & $d$ & OCN221 & GCGTCTTCTTCCATCTCCAA \\
\hline & e & OCN216 & TGAGGTCGTCCACGTTCAT \\
\hline \multirow{8}{*}{ pril } & $5^{\prime} \cup p$ & OCN176 & ggactagtCGTCGACTCAAGAGCGGTA \\
\hline & $3^{\prime} \cup p$ & OCN 177 & gtttatccacgggatccA CGACCA GTCTCCA CGAC \\
\hline & 5' Dwn & OCN 178 & acgcacataacggatccTGACGGA GTCCTTGCTGA C \\
\hline & 3' Dwn & OCN 179 & ccgctcgagA CGGA A G CGTTGTCTTGC \\
\hline & b & OCN218 & GCGAGAACGGAGACGATG \\
\hline & c & OCN222 & GCCCGATACCCGTTTTTC \\
\hline & $d$ & OCN223 & ACGAAAGCAGTTCCGTCTTG \\
\hline & $\mathrm{e}$ & OCN219 & CTTCCTAATCCGGCTGGTC \\
\hline
\end{tabular}

Table 1. Primers used for genetic analysis in $\mathrm{H}$ aloferax volcanii. 


\begin{tabular}{llll} 
Nucleotide & Condition & $\mathbf{V} \max \left(\mathbf{p m o l} . \mathbf{m i n}^{-1}\right)$ & $\mathbf{K m}(\mathbf{m M})$ \\
\hline dNTP & $5 \mathrm{mM} \mathrm{M} \mathrm{g}$ & 1.12 & 60.5 \\
\cline { 2 - 4 } & $10 \mathrm{mM} \mathrm{M} \mathrm{g}^{2+}$ & 0.70 & 5.0 \\
& $+5 \mathrm{mM} \mathrm{M} \mathrm{n}^{2+}$ & 5.9 & 198.0 \\
\hline NTP & $10 \mathrm{mM} \mathrm{M} \mathrm{g}^{2+}$ & 0.88 & 27.5 \\
& $+5 \mathrm{mM} \mathrm{M} \mathrm{n}^{2+}$ & & \\
\hline
\end{tabular}

T able 2. K inetic parameters for $P$. abyssi D NA primase under different metal ions conditions. 

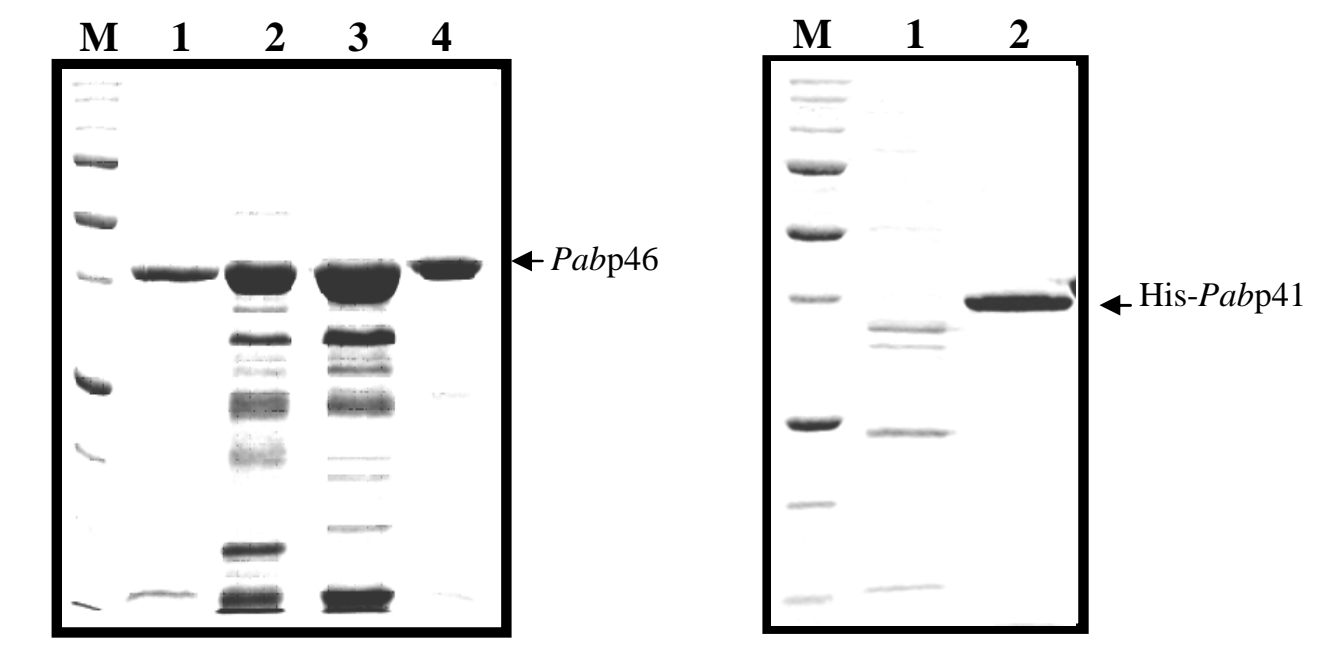

Figure

\section{FIG. 1}




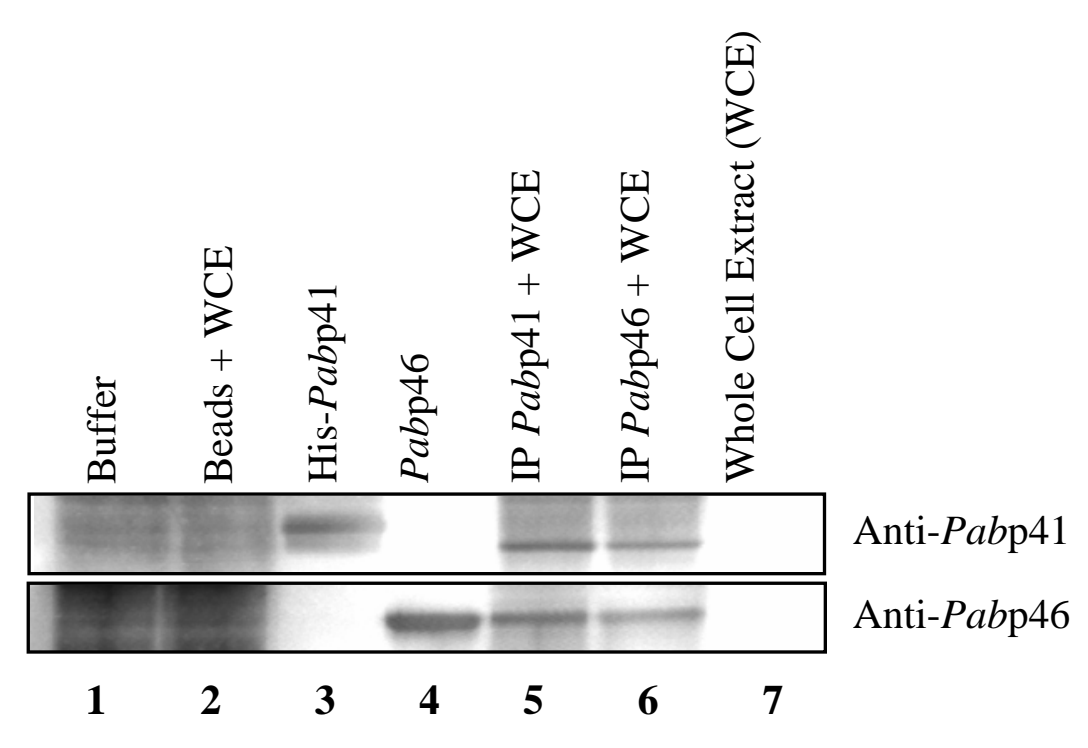

Figure

\section{FIG. 2}

$\begin{array}{lllllll}1 & 2 & 3 & 4 & 5 & 6 & 7\end{array}$


Fig. 3

(a)
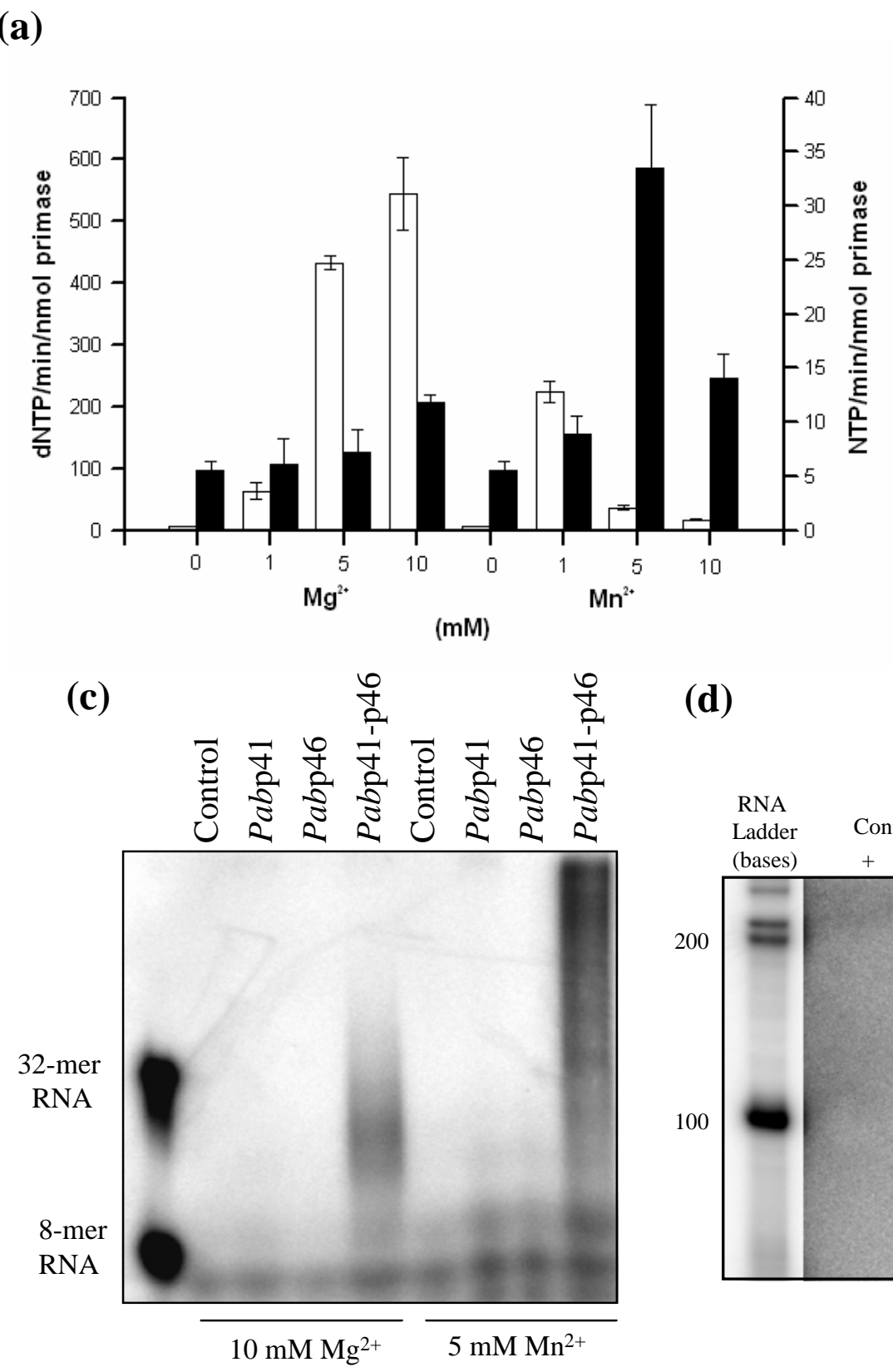

(d)

(b)

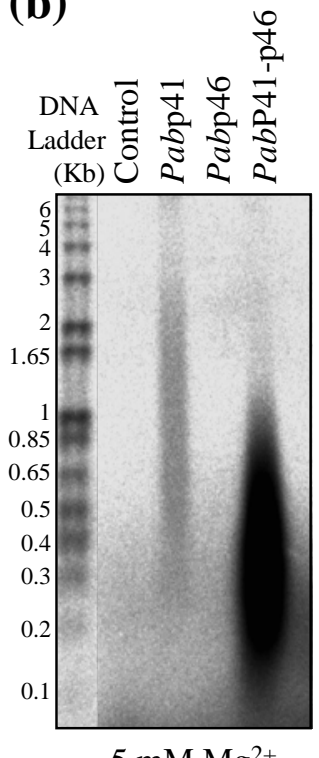

$5 \mathrm{mM} \mathrm{M} \mathrm{g}{ }^{2+}$

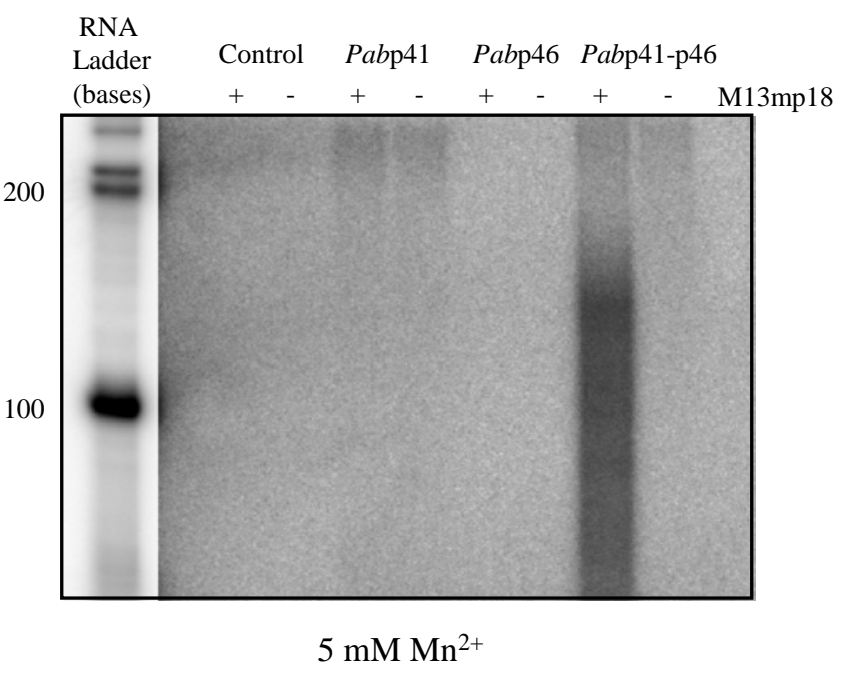


FIG. 4

(a)

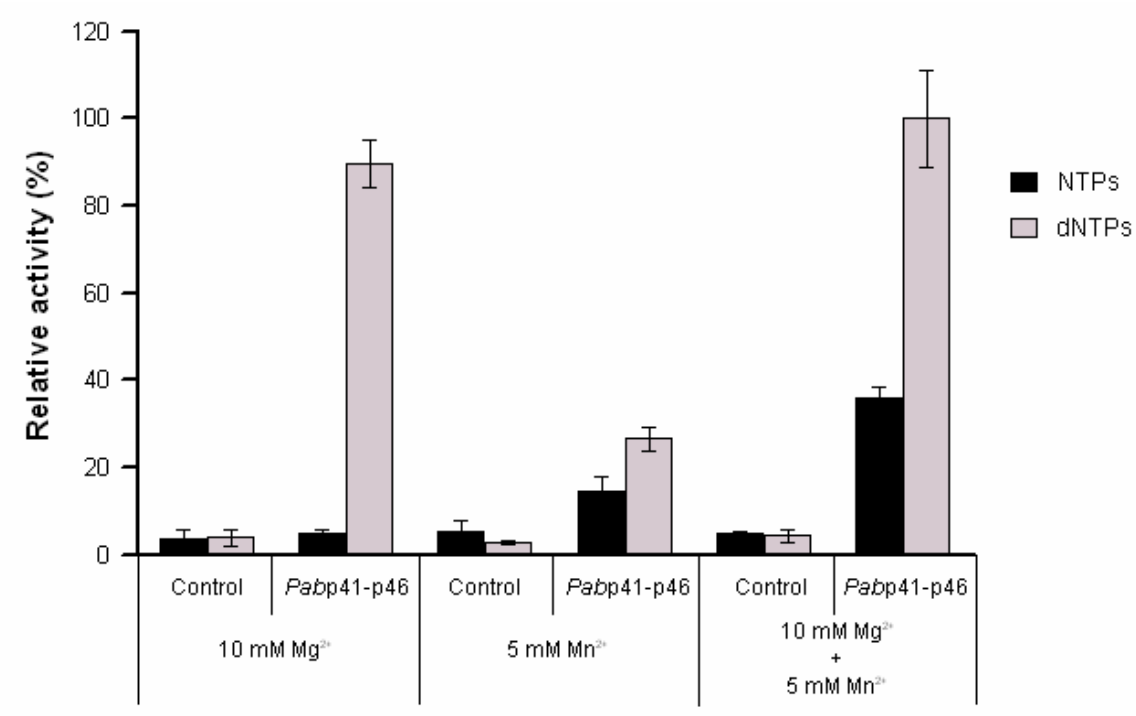

(b)
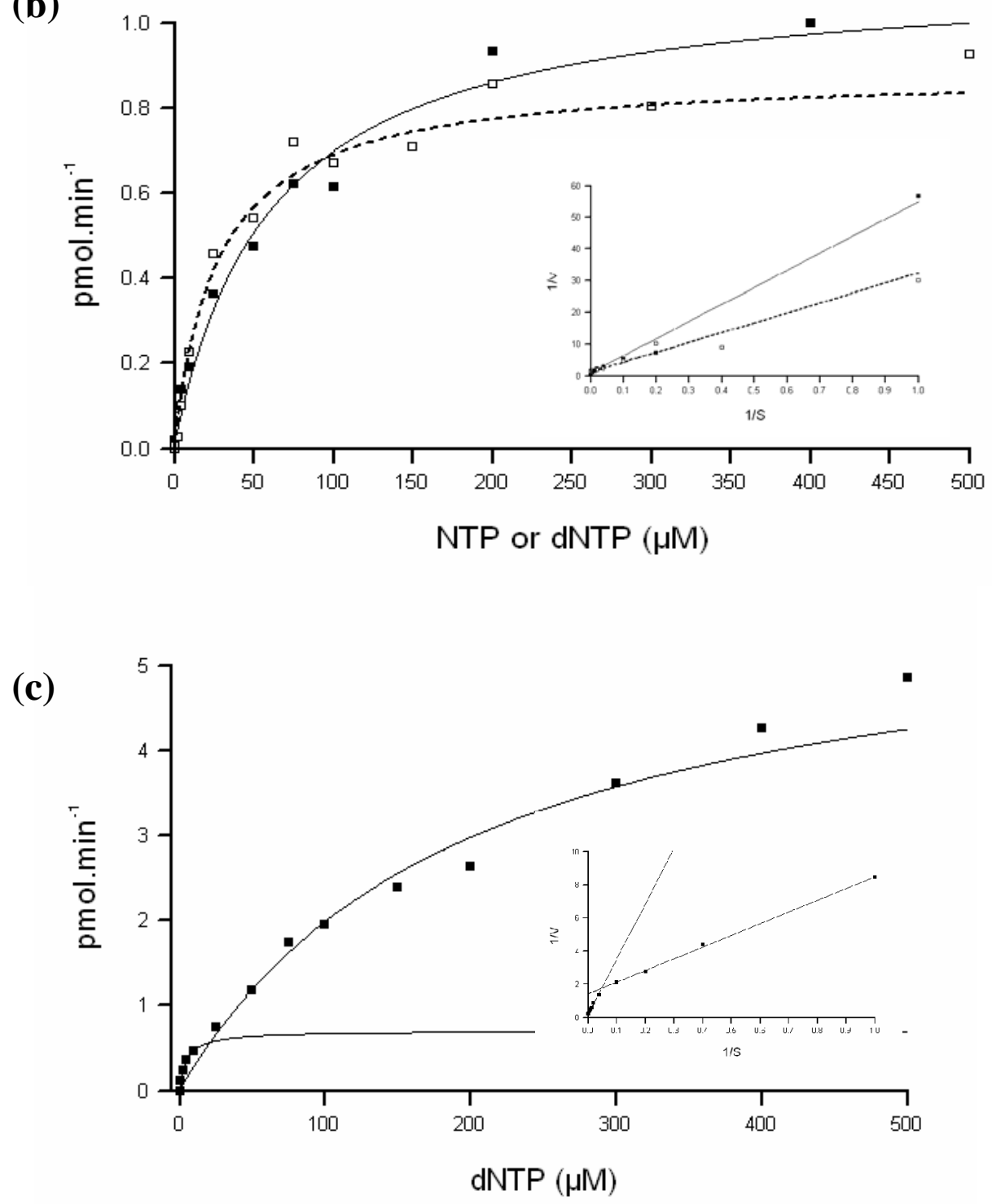
FIG. 5

(a)

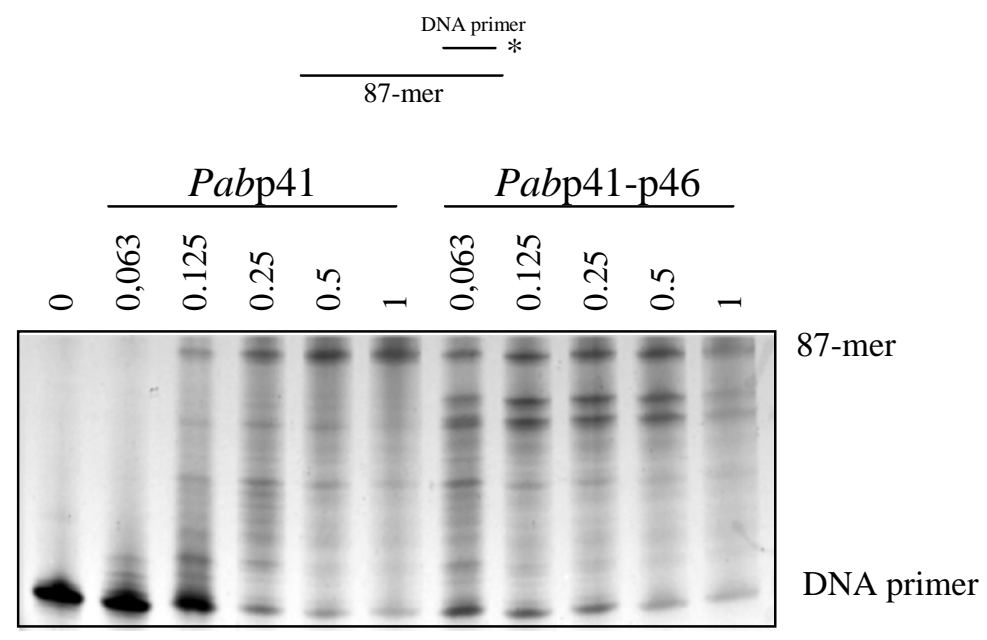

(b)

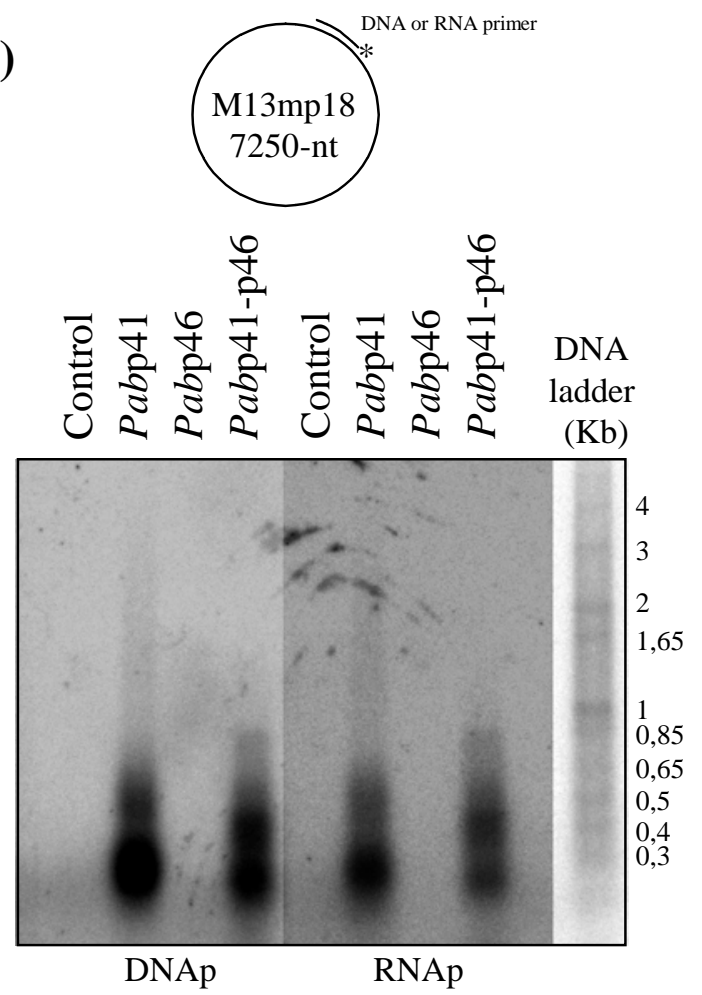




\section{FIG. 6}
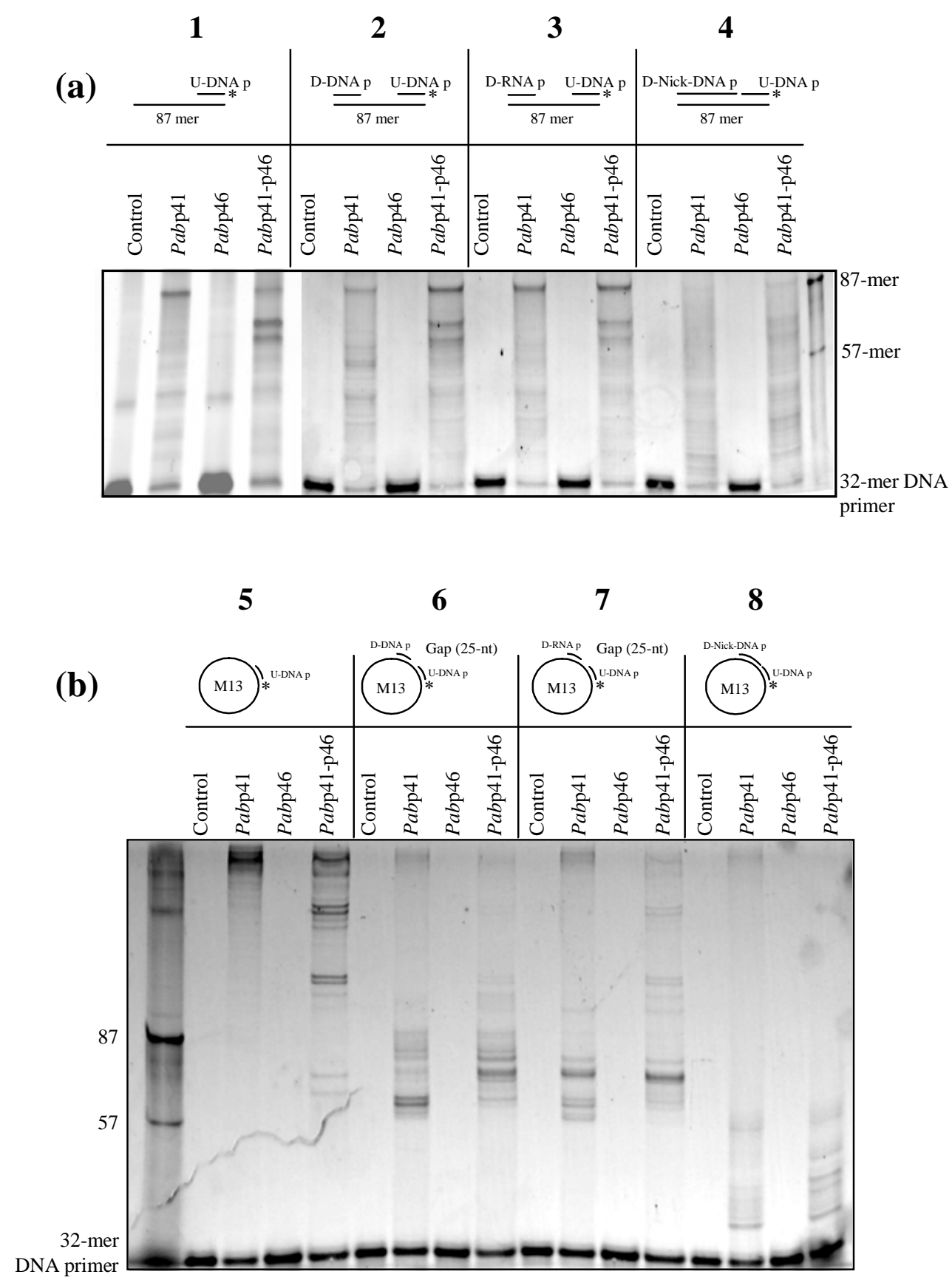
